\title{
Tinjauan Literatur
}

\section{PERBANDINGAN qSOFA DAN SIRS DALAM MENGIDENTIFIKASI PASIEN DENGAN SEPSIS DAN MEMPREDIKSI MORTALITASNYA: REVIEW ARTIKEL}

\begin{abstract}
Efris Kartika Sari ${ }^{\star 凶}$
Abstrak

Sepsis merupakan penyebab utama kondisi sakit kritis dan mortalitas di dunia. Kondisi sepsis membutuhkan identifikasi segera karena penundaan identifikasi sepsis dapat berakibat pada peningkatan angka mortalitas pasien. Review artikel ini bertujuan untuk menganalisis perbandingan qSOFA dan SIRS dalam mengidentifikasi pasien dengan sepsis dan memprediksi mortalitasnya. Artikel didapatkan melalui pencarian menggunakan online database yaitu PubMed dengan menggunakan kata kunci qSOFA, SIRS, sepsis. Hasil pencarian mengidentifikasi hasil yang relevan dengan kata kunci sejumlah 35 artikel, kemudian dipilih 9 artikel untuk dikaji. Hasilnya terdapat satu studi pada 886 pasien yang menyatakan bahwa qSOFA dan SIRS belum optimal dalam mengidentifikasi sepsis. Terdapat dua studi dengan jumlah total 3.542 pasien yang menyatakan bahwa kriteria SIRS lebih baik dalam mengidentifikasi sepsis dan memprediksi mortalitas pasien. Selanjutnya, terdapat enam studi dengan jumlah total 167.172 pasien yang menyatakan keunggulan qSOFA dibandingkan dengan SIRS dalam mengidentifikasi sepsis dan memprediksi mortalitas pasien. Skor qSOFA lebih unggul dari kriteria SIRS dalam mengidentifikasi pasien sepsis dengan disfungsi organ yang berisiko tinggi mengalami kematian, sedangkan kriteria SIRS lebih unggul dari skor qSOFA dalam mengidentifikasi pasien sepsis yang belum mengalami disfungsi organ dan berisiko rendah mengalami kematian.
\end{abstract}

Kata kunci: qSOFA, SIRS, sepsis, mortalitas.

\section{COMPARISON OF qSOFA AND SIRS FOR IDENTIFYING PATIENT WITH SEPSIS AND PREDICTING ITS MORTALITY: ARTICLE REVIEW}

\begin{abstract}
Sepsis is a leading cause of critical illness and mortality in the world. Sepsis condition requires early identification because late identification of sepsis may lead to an increase in patient mortality. The purpose of this article review was to compare the ability of qSOFA and SIRS for identifying patients with sepsis and predicting its mortalities. Studies reporting on qSOFA and SIRS were searched using PubMed by using keywords qSOFA, SIRS, sepsis. The search results identified 35 relevant articles, then 9 articles were selected for review. The results showed one study with 886 patients reported that both of qSOFA and SIRS were not optimal in identifying sepsis. Two studies with a total of 3.542 patients reported that SIRS criteria were better in identifying sepsis and predicting mortality. Six studies with a total of 167.172 patients reported the superiority of qSOFA compared to SIRS in identifying sepsis and predicting mortality. The qSOFA score is superior compared to SIRS criteria in identifying sepsis patients with organ dysfunction who were at high risk of mortality, while the SIRS criteria are superior compared to qSOFA score in identifying sepsis patients without organ dysfunction who were at low risk of mortality.

Keywords: qSOFA, SIRS, sepsis, mortality.

* Jurusan IImu Keperawatan, Fakultas Kedokteran, Universitas Brawijaya

E-mail: efriskartika@ub.ac.id
\end{abstract}




\section{Pendahuluan}

Beberapa studi melaporkan kontroversi tentang penggunaan kriteria SIRS dalam mengidentifikasi sepsis. Kondisi noninfeksi seperti trauma, luka bakar, pankreatitis dan ischaemia-reperfusion injury merupakan kondisi yang juga menyebabkan SIRS. Selain itu, pada tingkat molekuler, kondisi inflamasi oleh sebab infeksi maupun noninfeksi memiliki kemiripan yaitu sama-sama mengaktifkan koagulasi, sitokin inflamasi, dan mekanisme perbaikan jaringan (tissue repair pathways) sehingga sulit membedakan keduanya pada tahap awal penyakit. Pasien dengan gangguan sistem imun juga menunjukkan variasi respons tubuh terhadap infeksi, tergantung pada proses kronis penyakit. Sebagian besar pasien yang mengalami infeksi lokal juga menunjukkan gejala SIRS, maka kondisi infeksi lokal juga dapat salah didiagnosis sebagai sepsis.8,9

Sepsis-3 Task Force mendefinisikan ulang sepsis sebagai disfungsi organ yang mengancam jiwa yang disebabkan oleh disregulasi respons tubuh terhadap infeksi. Disfungsi organ ditandai oleh peningkatan minimal dua poin pada skor the Sequential (Sepsis-related) Organ Failure Assessment (SOFA). Pada praktiknya, penilaian sepsis dengan skor SOFA membutuhkan pemeriksaan laboratorium, dan kriteria tersebut jarang digunakan di luar ruang rawat intensif. Mempertimbangkan hal tersebut, the Sepsis-3 Task Force memperkenalkan alat identifikasi yang lebih sederhana yaitu the quick Sequential Organ Failure Assessment (qSOFA), 5,10

Skor qSOFA dikembangkan untuk identifikasi kondisi disfungsi organ pada pasien dengan sepsis. Pedoman sepsis yang terbaru menekankan kebutuhan akan diagnosis dini dan penatalaksanaan cepat selama proses sepsis berlangsung. ${ }^{9}$ Namun, beberapa studi menunjukkan hasil yang beragam terhadap akurasi qSOFA dan SIRS dalam mendeteksi sepsis dan mortalitasnya. Review artikel ini bertujuan untuk menganalisis perbandingan qSOFA dan SIRS dalam mengidentifikasi pasien dengan sepsis dan memprediksi mortalitasnya, pada setting unit gawat darurat, ruang rawat intensif (ICU), dan ruang perawatan non-ICU.

\section{Metode Penelurusan}

Artikel didapatkan melalui pencarian menggunakan online database yaitu PubMed dengan menggunakan kata kunci qSOFA, SIRS, sepsis. Kriteria inklusi yaitu artikel berupa hasil penelitian (original research), artikel penelitian tentang SOFA dan qSOFA dalam memprediksi mortalitas pasien dengan infeksi. Kriteria eksklusi yaitu artikel berupa systematic review atau meta analisis. Artikel dibatasi mulai tahun terbit tanggal 01 Januari 2015 sampai dengan 08 September 2018 untuk memastikan bahwa artikel tersebut relevan dengan kondisi terkini.

\section{Perbedaan Kriteria SIRS dan Skor qSOFA}

Pada tahun 2016, The Task Force memperkenalkan quick SOFA (qSOFA) untuk memudahkan identifikasi pasien yang berisiko mengalami kematian akibat sepsis. ${ }^{17}$ Namun, fakta di lapangan menunjukkan satu tahun setelah pengenalan definisi baru sepsis, masih banyak rumah sakit yang menggunakan kriteria SIRS untuk mengidentifikasi sepsis dan sepsis berat. Hal tersebut didasarkan pada fakta bahwa sebanyak $88 \%$ pasien yang sebelumnya berdasarkan kriteria SIRS didiagnosis mengalami sepsis, tidak lagi dianggap mengalami sepsis. Terdapat kekhawatiran bahwa qSOFA yang ketat dalam mengidentifikasi pasien sepsis dapat berakibat tidak ditanganinya pasien yang sebenarnya mengalami sepsis namun tidak memenuhi skor qSOFA. ${ }^{14}$ 
Kriteria SIRS mendefinisikan sepsis sebagai kombinasi infeksi dan SIRS $(\geq 2)$. Empat kriteria SIRS yaitu: takikardia (denyut jantung $>90$ kali/ menit), takipnea (frekuensi pernafasan $>20$ (menit), demam atau hipotermia (suhu tubuh $\geq 38,3{ }^{\circ} \mathrm{C}$ atau $<36{ }^{\circ} \mathrm{C}$ ), dan leukositosis atau leukopenia (jumlah leukosit $>12,000 \mathrm{sel} / \mu \mathrm{L}$ atau $<4000 / \mu \mathrm{L})$. Selanjutnya, kriteria klinis sepsis berat yaitu kriteria SIRS ditambah satu tanda disfungsi organ atau hipoperfusi yaitu Glasgow Coma Scale (GCS) $<15$ atau menurun dari baseline, saturasi oksigen $<90 \%$ atau tekanan darah sistolik $<90 \mathrm{mmHg}$ (Tabel 1).6,10

Skor qSOFA diusulkan Sepsis 3 Task Force sebagai alat stratifikasi yang lebih spesifik daripada kriteria SIRS untuk kepentingan penilaian disfungsi organ, mengidentifikasi kondisi infeksi yang mengancam nyawa, memulai atau meningkatkan terapi sepsis secara tepat, dan merujuk pasien ke ruang rawat intensif. ${ }^{3}$ Skor qSOFA berkisar dari 0 hingga 3 , dengan satu poin diberikan untuk masing-masing tanda-tanda klinis berikut: tekanan darah sistolik $\leq 100 \mathrm{mmHg}$, frekuensi pernafasan $\geq 22 \mathrm{kali} / \mathrm{mnt}$, dan perubahan status mental. Perubahan status mental tidak terbatas pada nilai GCS $\leq 13$, tetapi mencakup perubahan status mental seperti disorientasi dan somnolen. Skor $\geq 2$ menandakan risiko lebih tinggi untuk peningkatan lama rawat inap atau peningkatan mortalitas (Tabel 1).4,15,16

\section{Perbandingan qSOFA dan SIRS dalam Mengidentifikasi Sepsis dan Memprediksi Mortalitas pada Pasien dengan Infeksi}

Hasil pencarian mengidentifikasi hasil yang relevan dengan kata kunci sejumlah 35 artikel. Dari 35 artikel tersebut dipilih 9 artikel untuk dikaji (Tabel 2). Studi yang dikaji menggunakan partisipan pasien yang dicurigai atau telah didiagnosis mengalami infeksi, yang menjalani perawatan di rumah sakit. Studi tersebut membandingkan penggunaan qSOFA dan SIRS sebagai alat identifikasi sepsis, serta penggunaan qSOFA dan SIRS dalam memprediksi outcome pasien yang diidentifikasi mengalami sepsis.

Tabel 1. Kriteria SIRS dan Skor qSOFA. ${ }^{14}$

\begin{tabular}{ll}
\hline \multicolumn{1}{c}{ Kriteria SIRS $(\geq 2)$} & \multicolumn{1}{c}{ Skor qSOFA $(\geq 2)$} \\
\hline 1. Suhu tubuh $>38{ }^{\circ} \mathrm{C}$ atau $<36{ }^{\circ} \mathrm{C}$ & 1. Frekuensi pernafasan $\geq 22 \mathrm{kali} / \mathrm{menit}$ \\
2. Denyut jantung $>90 \mathrm{kali} / \mathrm{menit}$ & 2. Tekanan darah sistolik $\leq 100 \mathrm{mmHg}$ \\
3. Frekuensi pernafasan $>20$ kali/menit atau & 3. Perubahan status mental \\
$\mathrm{PaCO}{ }_{2}<4,3 \mathrm{kPa}$ & \\
$\begin{array}{l}\text { 4. Hasil hitung sel darah putih }<4.000 \mathrm{sel} / \mathrm{mm}^{3} \\
\text { atau }>12.000 \mathrm{sel} / \mathrm{mm}^{3} \text { atau }>10 \% \text { berbentuk }\end{array}$ & \\
imatur & \\
\hline
\end{tabular}

Keterangan: SIRS= systemic inflammatory response syndrome; qSOFA= quick sequential organ failure assessment. 
Tabel 2. Ringkasan studi perbandingan qSOFA dan SIRS dalam mengidentifikasi sepsis dan memprediksi mortalitas pada pasien dengan infeksi.

\begin{tabular}{|c|c|c|c|c|}
\hline Studi & Metode & Partisipan & Hasil & Kesimpulan \\
\hline Tusgul6 & Studi retrospektif & $\begin{array}{l}886 \text { pasien yang } \\
\text { dicurigai, dan } \\
\text { telah didiagno- } \\
\text { sis infeksi di unit } \\
\text { gawat darurat }\end{array}$ & $\begin{array}{l}\text { Sensitivitas qSOFA } \\
\text { dan SIRS untuk mor- } \\
\text { talitas dalam waktu } 48 \\
\text { jam masing-masing } \\
\text { yaitu } 68 \% \text { dan } 64 \% \\
\text { (pre hospital), serta } \\
60 \% \text { dan } 80 \% \text { (saat } \\
\text { triase). }\end{array}$ & $\begin{array}{l}\text { qSOFA dan SIRS } \\
\text { belum optimal da- } \\
\text { lam identifikasi } \\
\text { awal pasien } \\
\text { dengan infeksi } \\
\text { yang berisiko me- } \\
\text { ngalami komplikasi } \\
\text { pada setting pre } \\
\text { hospital dan pada } \\
\text { saat triase di unit } \\
\text { gawat darurat. }\end{array}$ \\
\hline Finkelsztein ${ }^{10}$ & Studi kohort & $\begin{array}{l}152 \text { pasien } \\
\text { yang dicurigai } \\
\text { mengalami in- } \\
\text { feksi di unit } \\
\text { gawat darurat. }\end{array}$ & $\begin{array}{l}\text { qSOFA menunjukkan } \\
\text { nilai area under the } \\
\text { receiver operating } \\
\text { characteristic curve } \\
\text { (AUC), } 0.74 ; 95 \% \text { con- } \\
\text { fidence intervals (CI), } \\
0.66-0.81] \text {, dan SIRS } \\
\text { yaitu AUC, } 0.59 ; 95 \% \\
\mathrm{Cl}, 0.51-0.67 ; p= \\
0.03) \text {. dalam mem- } \\
\text { prediksi in hospital } \\
\text { mortality }\end{array}$ & $\begin{array}{l}\text { qSOFA memiliki } \\
\text { akurasi yang lebih } \\
\text { baik daripada SIRS } \\
\text { dalam memprediksi } \\
\text { mortalitas pasien } \\
\text { yang dicurigai me- } \\
\text { ngalami infeksi dan } \\
\text { perlu dirawat di } \\
\text { ruang rawat inten- } \\
\text { sif. }\end{array}$ \\
\hline $\begin{array}{l}\text { Giamarellos- } \\
\text { Bourboulis }{ }^{11}\end{array}$ & Studi kohort & $\begin{array}{l}1058 \text { pasien } \\
\text { dengan infeksi } \\
\text { yang dirawat di } \\
\text { ICU dan } 3346 \\
\text { pasien dengan } \\
\text { infeksi yang } \\
\text { dirawat di ruang } \\
\text { non ICU }\end{array}$ & $\begin{array}{l}\text { Pada ruang non-ICU, } \\
\text { sensitivitas qSOFA } \\
\text { untuk mendiagnosis } \\
\text { disfungsi organ yaitu } \\
48,7 \% \text {, sedangkan } \\
\text { SIRS ( } \geq 3 \text { ) yaitu } \\
72,5 \%(p<0,0001)\end{array}$ & $\begin{array}{l}\text { Skor qSOFA me- } \\
\text { miliki sensitivitas } \\
\text { yang kurang apabi- } \\
\text { la dibandingkan } \\
\text { dengan SIRS untuk } \\
\text { penilaian risiko dini } \\
\text { (early risk assess- } \\
\text { ment). }\end{array}$ \\
\hline Donnelly ${ }^{1}$ & Studi retrospektif & $\begin{array}{l}\text { 2,593 pasien } \\
\text { dengan infeksi }\end{array}$ & $\begin{array}{l}\text { Angka in-hospital mor- } \\
\text { tality pasien yang di- } \\
\text { identifikasi sepsis } \\
\text { dengan qSOFA adalah } \\
67 / 295 ; 22.7 \% \text {, se- } \\
\text { dangkan SIRS adalah } \\
\text { 128/1,392; } 9.2 \% \text {. Mor- } \\
\text { talitas pasien satu } \\
\text { tahun setelah keluar } \\
\text { rumah sakit (mortality } \\
\text { post-discharge) pasien } \\
\text { yang diidentifikasi sep- } \\
\text { sis dengan qSOFA } \\
\text { adalah } \\
29,4 \text { per } 100 \text { orang/ } \\
\text { tahun; } \mathrm{CI} 22.3-38.7 \\
\text { sedangkan SIRS } 14,7 \text {; } \\
\mathrm{Cl} 12.5-17.2 \text {. }\end{array}$ & $\begin{array}{l}\text { Mendukung } \\
\text { penggunaan } \\
\text { qSOFA untuk iden- } \\
\text { tifikasi pasien in- } \\
\text { feksi yang berisiko } \\
\text { tinggi mengalami } \\
\text { perburukan. }\end{array}$ \\
\hline
\end{tabular}


Lanjutan Tabel 2. Ringkasan studi perbandingan qSOFA dan SIRS dalam mengidentifikasi sepsis dan memprediksi mortalitas pada pasien dengan infeksi.

\begin{tabular}{|c|c|c|c|c|}
\hline Studi & Metode & Partisipan & Hasil & Kesimpulan \\
\hline Churpek $^{13}$ & Studi retrospektif & $\begin{array}{l}\text { 30,677 pasien } \\
\text { dengan infeksi } \\
\text { di ruang non- } \\
\text { ICU }\end{array}$ & $\begin{array}{l}\text { Sensitivitas dan spe- } \\
\text { sifisitas qSOFA ( } \geq 2) \\
\text { dalam memprediksi in } \\
\text { hospital mortality ada- } \\
\text { lah } 88,9 \% \text { dan } 24,4 \% \text {. } \\
\text { Sedangkan sensitivitas } \\
\text { dan spesifisitas SIRS } \\
(\geq 2) \text { adalah } 97 \% \text { dan } \\
15,7 \% \text {. } \\
\text { qSOFA ( } \geq 2) \text { dan SIRS } \\
(\geq 2) \text { masing-masing } \\
\text { memiliki sensitivitas } \\
68,7 \% \text { dan } 93,8 \% \text {, } \\
\text { serta spesifisitas } \\
63,5 \% \text { dan } 12,3 \% \\
\text { dalam memprediksi in } \\
\text { hospital mortality. }\end{array}$ & $\begin{array}{l}\text { qSOFA mungkin } \\
\text { lebih unggul dari } \\
\text { kriteria SIRS dalam } \\
\text { memprediksi } \\
\text { in hospital mortality } \\
\text { pada pasien } \\
\text { dengan pneumonia } \\
\text { di unit gawat da- } \\
\text { rurat. } \\
\text { qSOFA lebih akurat } \\
\text { dalam memprediksi } \\
\text { in hospital mortality } \\
\text { dan transfer pasien } \\
\text { ke ICU. }\end{array}$ \\
\hline $\begin{array}{l}\text { Van der } \\
\text { Woude }\end{array}$ & Studi retrospektif & $\begin{array}{l}198 \text { pasien } \\
\text { yang dicurigai } \\
\text { mengalami in- } \\
\text { feksi di unit } \\
\text { gawat darurat. }\end{array}$ & $\begin{array}{l}\text { Skor qSOFA dan SIRS } \\
\geq 2 \text { menunjukkan sen- } \\
\text { sitivitas } 33,3 \% \text { dan } \\
61,9 \% \text {, serta spesifisi- } \\
\text { tas } 93.7 \% \\
\text { dan } 56.9 \% \text { dalam } \\
\text { memprediksi } \\
\text { in-hospital mortality. }\end{array}$ & $\begin{array}{l}\text { qSOFA memiliki } \\
\text { kemampuan lebih } \\
\text { rendah dalam } \\
\text { mengklasifikasikan } \\
\text { pasien dengan } \\
\text { risiko kematian } \\
\text { tinggi apabila } \\
\text { dibandingkan } \\
\text { dengan SIRS. }\end{array}$ \\
\hline Gupta15 & Studi retrospektif & $\begin{array}{l}\text { 132,704 pasien } \\
\text { dengan diagno- } \\
\text { sis primer sep- } \\
\text { sis, sepsis be- } \\
\text { rat, syok septik, } \\
\text { dan unspecified } \\
\text { sepsis, di unit } \\
\text { gawat darurat. }\end{array}$ & 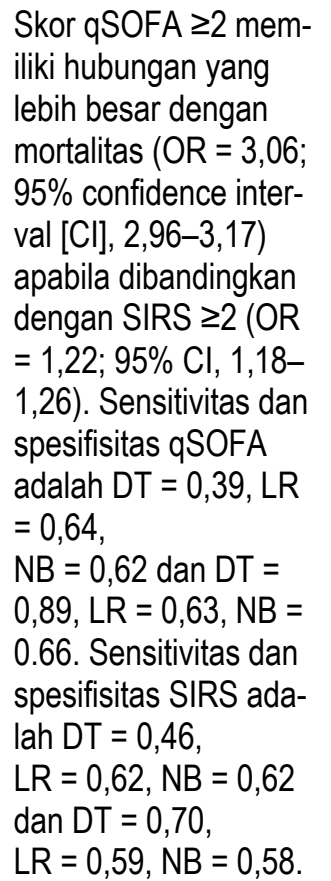 & $\begin{array}{l}\text { qSOFA merupakan } \\
\text { kriteria diagnostik } \\
\text { yang lebih baik } \\
\text { daripada SIRS, dan } \\
\text { qSOFA mampu } \\
\text { memprediksi mor- } \\
\text { talitas lebih baik } \\
\text { daripada SIRS. }\end{array}$ \\
\hline
\end{tabular}


Lanjutan Tabel 2. Ringkasan studi perbandingan qSOFA dan SIRS dalam mengidentifikasi sepsis dan memprediksi mortalitas pada pasien dengan infeksi.

\begin{tabular}{|c|c|c|c|c|}
\hline Studi & Metode & Partisipan & Hasil & Kesimpulan \\
\hline Blanco $^{16}$ & Studi kohort & $\begin{array}{l}519 \text { pasien } \\
\text { dengan infeksi }\end{array}$ & $\begin{array}{l}\text { Akurasi prognostik } \\
\text { qSOFA (AUROC 0,80, } \\
95 \% \text { CI 0,73-0,87) } \\
\text { dalam memprediksi } \\
\text { mortalitas (28-day } \\
\text { mortality) sama } \\
\text { dengan SOFA } \\
\text { (AUROC } 0,79,0,71- \\
0,87 ; p=0,1) \text {, dan } \\
\text { lebih baik daripada } \\
\text { SIRS (AUROC } 0,61 \text {, } \\
0,52-0,71 ; p<0,001 \text { ). }\end{array}$ & $\begin{array}{l}\text { Mendukung } \\
\text { penggunaan } \\
\text { qSOFA sebagai } \\
\text { alat triase untuk } \\
\text { mengidentifikasi } \\
\text { pasien dengan } \\
\text { sepsis dan berisiko } \\
\text { tinggi mengalami } \\
\text { perburukan. }\end{array}$ \\
\hline
\end{tabular}

Metode klasifikasi yang berbeda tentunya akan memberikan hasil yang berbeda dalam menilai sepsis. Sejumlah penelitian telah mengevaluasi metode untuk mengidentifikasi pasien dengan risiko tinggi infeksi di berbagai setting ruang perawatan. Studi Tusgul et al (2017) pada 886 pasien yang dicurigai dan telah didiagnosis mengalami infeksi di unit gawat darurat menunjukkan penggunaan qSOFA di unit gawat darurat menunjukkan hasil kriteria SIRS lebih baik daripada skor qSOFA dalam mengidentifikasi sepsis, namun qSOFA lebih baik daripada SIRS dalam mengidentifikasi pasien infeksi yang berisiko mengalami kematian dalam waktu 48 jam. Kriteria SIRS memiliki sensitivitas yang lebih baik sehingga penggunaannya efektif sebagai screening tool infeksi. Di sisi lain, qSOFA lebih baik dalam mengidentifikasi pasien infeksi yang berisiko mengalami kematian sebab qSOFA memasukkan disfungsi organ dalam penilaiannya, sedangkan SIRS tidak memasukkan disfungsi organ yang dialami oleh pasien dengan infeksi berat.6,18,19

Skor qSOFA dengan nilai spesifisitas yang tinggi menunjukkan bahwa qSOFA bermanfaat untuk mengidentifikasi pasien terinfeksi yang berisiko mengalami perburukan kondisi. Oleh karena itu, qSOFA dapat digunakan sebagai pertimbangan untuk dilakukannya pemeriksaan lebih lanjut terhadap kondisi disfungsi organ pada pasien yang terinfeksi, memulai meningkatkan terapi yang sesuai, dan sebagai pertimbangan untuk merujuk pasien ke ruang rawat intensif. Namun, nilai sensitivitas qSOFA yang rendah dapat berarti pasien yang sebenarnya berisiko tinggi untuk mengalami perburukan atau kematian dapat tidak teridentifikasi dengan tepat. ${ }^{20}$

Studi oleh Giamarellos-Bourboulis et al (2017) dan Van der Woude et al (2018), dengan jumlah total 3.542 pasien menunjukkan qSOFA memiliki kemampuan lebih rendah dalam penilaian risiko dini (early risk assessment), dan mengidentifikasi pasien dengan risiko kematian tinggi apabila dibandingkan dengan SIRS. Beberapa hal yang menjadikan penggunaan qSOFA masih menjadi kontroversi yaitu pertama, qSOFA didesain dan diuji untuk diterapkan pada pasien yang dicurigai mengalami infeksi, bukan untuk membedakan pasien yang mengalami infeksi dan tidak. Kedua, penilaian status mental dapat bervariasi, dipengaruhi oleh situasi sehingga dapat berpengaruh terhadap validitas qSOFA. SOFA hanya menilai apakah status mental pasien abnormal, tidak mengevaluasi perubahan status mental pasien dari kondisi awal. 
Ketiga, qSOFA tidak memasukkan kadar serum laktat yang telah diusulkan sebagai alat skrining untuk sepsis. ${ }^{20,21}$

Selanjutnya, terdapat enam studi dengan jumlah total 167.172 pasien yang menyatakan keunggulan qSOFA dibandingkan dengan SIRS. Pengamatan terhadap kriteria SIRS menunjukkan bahwa semua variabel, kecuali frekuensi pernafasan, memiliki hubungan yang lemah dengan in hospital mortality. Namun pada kriteria qSOFA, semua variabel memiliki hubungan yang kuat dengan in hospital mortality, dengan variabel Glasgow Coma Scale yang memiliki hubungan terkuat. Angka mortalitas menunjukkan tren kenaikan seiring dengan peningkatan skor qSOFA, namun cenderung stagnan dengan skor SIRS. Peningkatan setiap unit skor qSOFA memberikan lebih banyak informasi tentang risiko kematian daripada perubahan skor SIRS.

Studi lebih lanjut menemukan bahwa walaupun skor qSOFA $\geq 2$ memiliki hubungan yang lebih kuat dengan in hospital mortality di unit gawat darurat daripada kriteria SIRS $\geq 2$, namun qSOFA memiliki sensitivitas yang rendah. Sensitivitas yang rendah tersebut dapat menyebabkan tidak terdiagnosisnya pasien yang mengalami sepsis. Tidak terdiagnosisnya pasien sepsis pada tahap awal dapat menyebabkan outcome yang buruk, karena penatalaksanaan yang cepat dan tepat sangat penting pada pasien sepsis. Di sisi lain, sensitivitas SIRS yang tinggi dapat mengakibatkan diagnosis berlebihan (over diagnosis) pasien sepsis sehingga pasien mendapat tindakan penatalaksanaan yang sebenarnya tidak dibutuhkan. Hal tersebut tentunya menjadi beban di ruang rawat intensif. ${ }^{17}$

Spesifisitas tinggi qSOFA memberikan manfaat besar untuk skrining pasien yang diduga mengalami infeksi dan memiliki potensi berkembang menjadi kondisi disfungsi organ. Terpenuhinya dua atau lebih skor qSOFA dapat digunakan sebagai pertimbangan untuk memulai terapi atau memindahkan pasien ke ruang rawat intensif. Namun, karena qSOFA memiliki sensitivitas rendah, maka perlu menilai kembali risiko terjadinya bias atau tidak terdiagnosisnya pasien yang mengalami fase awal sepsis. Solusi yang dimunculkan yaitu melengkapi penilaian pasien dengan menggunakan biomarker seperti laktat atau biomarker penanda sepsis lainnya. Oleh karena itu, penggunaan kriteria qSOFA disarankan sebagai identifikasi sepsis di luar setting ruang rawat intensif, dan mendorong tindakan lebih lanjut pada pasien yang dicurigai mengalami sepsis. ${ }^{20}$

\section{Kesimpulan}

Skor qSOFA memiliki spesifisitas tinggi sehingga lebih unggul dari kriteria SIRS dalam mengidentifikasi pasien sepsis dengan disfungsi organ yang berisiko tinggi mengalami kematian. Kriteria SIRS memiliki sensitivitas tinggi sehingga lebih unggul dari skor qSOFA dalam mengidentifikasi pasien sepsis yang belum mengalami disfungsi organ dan berisiko rendah mengalami kematian. Studi lebih lanjut diperlukan untuk mengetahui kemampuan kriteria qSOFA dan SIRS dalam mengidentifikasi sepsis pada setting unit gawat darurat, ruang rawat intensif, dan ruang rawat nonintensif.

\section{Daftar Pustaka}

1. Donnelly JP, Safford MM, Shapiro NI, Baddley JW, Wang HE. Application of the Third International Consensus Definitions for Sepsis (Sepsis-3) Classifications in a Population-Based Cohort: The Reasons for Geographic and Racial Differences in Stroke Study. Lancet Infect Dis. 2017; 17 (6):661-70. 
2. Samsudin Mul, Liu N, Prabhakar SM, Chong S-L, Lye WK, Koh ZX, et al. A Novel Heart Rate Variability Based Risk Prediction Model for Septic Patients Presenting to the Emergency Department. Medicine. 2018; 97(23):e10866.

3. Askim $\AA$, Moser F, Gustad LT, Stene $H$, Gundersen M, Åsvold BO, et al. Poor Performance of Quick-SOFA (qSOFA) Score in Predicting Severe Sepsis and Mortality -A Prospective Study of Patients Admitted with Infection to The Emergency Department. Resuscitation and Emergency Medicine. 2017; 25(56):1-9.

4. Jiang J, Yang J, Mei J, Jin Y, Lu Y. Headto-Head Comparison of qSOFA and SIRS Criteria in Predicting the Mortality of Infected Patients in the Emergency Department: a Meta-Analysis. Scandinavian Journal of Trauma, Resuscitation and Emergency Medicine. 2018; 26(56):1-11.

5. Camm CF, Hayward G, Elias TCN, Bowen oST, Hassanzadeh R, Fanshawe $T$, et al. Sepsis Recognition Tools in Acute Ambulatory Care: Associations with Process of Care and Clinical Outcomes in a Service Evaluation of an Emergency Multidisciplinary Unit in Oxfordshire. BMJ Open. 2018; 8:e020497.

6. Tusgul S, Carron P-N, Yersin B, Calandra T, Dami F. Low Sensitivity of qSOFA, SIRS Criteria and Sepsis Definition to Identify Infected Patients at Risk of Complication in the Prehospital Setting and at the Emergency Department Triage. Scandinavian Journal of Trauma, Resuscitation and Emergency Medicine. 2017; 25(108):1 $-7$.

7. Usman OA, Usman AA, Ward MA. Comparison of SIRS, qSOFA, and NEWS for the Early Identification of Sepsis in the Emergency Department. American Journal of Emergency Medicine. 2019;37:1490-7.

8. Song J-U, Sin CK, Park HK, Shim SR, Lee J. Performance of the Quick Sequential (Sepsis-Related) Organ Failure Assess- ment Score as a Prognostic Tool in Infected Patients Outside the Intensive Care Unit: a Systematic Review and MetaAnalysis. Critical Care. 2018; 22(28):1-13.

9. Gül $F$, Arslantaş MK, Cinel I, Kumar A. Changing Defnitions of Sepsis. Turk J Anaesthesiol Reanim. 2017; 45:129-38.

10. Finkelsztein EJ, Jones DS, Ma KC, Pabón MA, Delgado T, Nakahira K, et al. Comparison of qSOFA and SIRS for Predicting Adverse Outcomes of Patients with Suspicion Of Sepsis Outside the Intensive Care Unit. Critical Care. 2017; 21(73):1-10.

11. Giamarellos-Bourboulis EJ, Tsaganos T, Tsangaris I, Lada M, Routsi C, Sinapidis D, et al. Validation of the New Sepsis-3 Definitions: Proposal for Improvement in Early Risk Identification. Clinical Microbiology and Infection. 2017; 23:104-9.

12. Muller M, Guignard V, Schefold JC, Leichtle AB, Exadaktylos AK, Pfortmueller CA. Utility of Quick Sepsis-Related Organ Failure Assessment (qSOFA) to Predict Outcome in Patients with Pneumonia. PLOS ONE. 2017; 12(2):e0188913.

13. Churpek MM, Snyder A, Han X, Sokol S, Pettit N, Howell MD, et al. Quick SepsisRelated Organ Failure Assessment, Systemic Inflammatory Response Syndrome, and Early Warning Scores for Detecting Clinical Deterioration in Infected Patients Outside the Intensive Care Unit. Am J Respir Crit Care Med. 2017; 195(7):90611.

14. Woude SWvd, Doormaal FFv, B.A. Hutten3 FJN, Holleman F. Classifying Sepsis Patients in the Emergency Department Using SIRS, qSOFA or MEWS. The Netherlands Journal of Medicine. 2018; 76 (4):158-66.

15. Gupta A, Liu T, Shepherd S, Paiva W. Using Statistical and Machine Learning Methods to Evaluate the Prognostic Accuracy of SIRS and qSOFA. Health Inform Res. 2018; 24(2):139-47. 
16. Boillat-Blanco Nm, Mbarack Z, Samaka J, Mlaganile T, Mamin A, Genton B, et al. Prognostic Value of quickSOFA as a of 28-Day Mortality among Febrile a Patients Presenting to Emergency Departments in Dar es Salaam, Tanzania. PLoS ONE. 2018; 13(6):e0197982.

17. Marik PE, Taeb AM. SIRS, qSOFA and New Sepsis Definition. J Thorac Dis. 2017; 9(4):943-5.

18. Bastoni $D$, Ticinesi A, Lauretani $F$, Calamai $S$, Catalano ML, Catania $P$, et al. Application of the Sepsis-3 Consensus Criteria in a Geriatric Acute Care Unit: a Prospective Study. J Clin Med. 2019; 8 (359):1-13.
19. Mecham ID, Dean NC, Wilson EL, Jephson AR, Lanspa MJ. The Association of qSOFA, SOFA, and SIRS with Mortality in Emergency Department Pneumonia Patients. ULJRI. 2018; 2(2):12-8.

20. Seymour CW, Liu VX, Iwashyna TJ, Brunkhorst FM, Rea TD, Scherag A, et al. Assessment of Clinical Criteria for Sepsis: for the Third International Consensus Definitions for Sepsis and Septic Shock (Sepsis-3). JAMA. 2016; 315(8):762-74.

21. Lo RSL, Leung LY, Brabrand M, Yeung CY, Chan SY, Lam CCY, et al. qSOFA is a Poor Predictor of Short-Term Mortality in All Patients: a Systematic Review of 410,000 Patients. J Clin Med. 2019; 8 (61):1-51. 